\title{
Flash Fiction by M.A. Tarkovsky \\ in the Context of Traditionalism: \\ the End of Direction vs. Different Prospect
}

\author{
Nikita A. Valyanov* \\ Siberian Federal University \\ 79 Svobodny, Krasnoyarsk, 660041, Russia
}

Received 22.11.2015, received in revised form 30.12.2015, accepted 26.02.2016

Flash fiction of the contemporary Siberian writer M.A. Tarkovsky is considered by critics and literary scholars in the context of late traditionalism. The motive of chaos and loss of national / traditional, relevant for the post-village literature are becoming mainstream in the prose of the writer and are manifested in the literary texts by R.V. Senchin, A. N. Varlamov, O.O. Pavlov and others. The writer himself defines the boundary of transition from the crisis of national identity to the problem of rethinking and native values preservation. The hero-intellectual is bound to return to the folk origins, reconnect with nature and feel the original existence. Another way of survival is constructed in the fictional world of M.A. Tarkovsky: the writer creates the ideology of asceticism and approves his own cultural and geographical marginality (A.I. Razuvalova). Understanding of tradition as the most important category of human existence is transformed in the flash fiction of the author.

Keywords: contemporary traditionalist prose, village prose, Mikhail Tarkovsky, neorealism, intellectual, peasant, hunter, craftsman, marginal, righteous man.

DOI: 10.17516/1997-1370-2016-9-5-1155-1165.

Research area: philology.

\section{Introduction}

Leading representatives of "village prose" V.I. Belov, F.A. Abramov, V.G. Rasputin, V.M. Shukshin, V.P. Astafiev spoke about destruction of Russian village as a national disaster at the turn of the 1960s - 1970s. The problem set is reflected in the journalism of the 1990s. In the essay "I Am Writing about the North" F.A. Abramov noted: “ < ..> The old village with its thousand years of history falls into oblivion these days $<\ldots>$, age-old foundations are being destroyed, the centuries-old ground on which our whole national culture was built is disappearing" (Abramov, 1993: 10-11). The decline of rural life also troubled V.I. Belov, who believed in the saving mission of peasantry: " $<\ldots$..> Peasantry is salvation of the nation and the state, the language, traditions and the culture of every nation" (Belov, 1993: 15).

V.G. Rasputin as well suffered from the unbearable pain caused by the destruction of the Christian foundations: " $<\ldots$.. $>$ the peasant became landless - the land was left without a master the society became homeless" (Rasputin 1991:

(C) Siberian Federal University. All rights reserved

* Corresponding author E-mail address: nick.valyanov@yandex.ru 
3-4). Unlike his predecessors F.A. Abramov and V.I. Belov, he understood that it was impossible the return the former traditions and values, however, memory recovery and respect for national traditions were the urgent needs. This idea became fundamental in the later texts by the writer ("Izba" and "To the Same Land"), where the author refers to the mythological images of the trickster and bogatyr maidens (Kovtun, 2014: 7-14), thus affirming the program of spiritual revival of the nation (Kovtun, 2013: 78).

The 1970s became the period of "sobering" and farewell for the "village prose". The leading texts by V.G. Rasputin ("The Last Term" and "Farewell to Matyora") and V.P. Astafiev ("The Last Tribute") became a symbol of the outgoing Russian village. The motif of loss became crosscutting in F.A. Abramov's latest novel tetralogy "Brothers and Sisters"- "House" (1978) (Kovtun 2010: 93-102). So, the main foundations - faith, home, and language are destroyed, spiritual connection between parents and children, brothers and sisters are lost, death of the peasant space, symbolizing the people's Rus is confirmed. Not the righteous (or the "keepers of antiquities") become the main characters of the narration, but the fringe, "arsonists", "rogues" and tricksters.

Russian literature of the 1980s - 1990s is characterized by eschatological poetics. The key works of that period ("The Fire" by V.G. Rasputin, "Sad Detective" and "Lyudochka" by V.P. Astafiev, "Everything is Ahead" by V.I. Belov and "Good-Bye Russia, Meet You in Paradise" by V.N. Krupin) symbolize a cry of despair, the loss of hope for enlightenment and revival of the peasant Russia. The final story by V.G. Rasputin “Ivan's Daughter, Ivan's Mother" (2003) manifests the breakdown of the nation that is forced to defend the right to exist - there is a call to resistance and self-identity (Kovtun, 2013: 78). A marginal character appears in the new literary space - a lost, forgotten character - he is looking for the true meaning of his own existence on the periphery of history. V.M. Shukshin was the first who spoke about destruction of "the ordinary man's" integrity. In the mature poetics of the writer the protagonist is at a crossroads, "he already knows how he does not want to live, but he does not know how to live" (Leiderman, 2003: 85). Not only Rasputin's old women, but also the characters of V.M Shukshin, V.P. Astafiev and B.P. Ekimov say goodbye to the world of harmony and true happiness. Premonition of their own Exodus and disappointment in existence become a key and symbolic motif of the story and are associated with an act of saying goodbye. K. Parthe states that in the post-village literature "apocalyptic motifs acquire more ideological and abstract forms of expression" (Parthe, 2004: 105). Thus, according to N.V. Belyaeva (Belyaeva, 2014: 231-232), the poetics of "premonition of the end" and "commemoration to everything" strengthened crisis effect of the prose of the $2000 \mathrm{~s}$ in the works by A.N. Varlamov ("The Sunken Ark"), O.O. Pavlov ("The End of the Century") and R.V. Senchin ("The Flood Zone"). At that, in the texts by R.V. Senchin a kind of invoice is issued to the authors of the "village prose", whose word could not not save the world from the new losses of land, abandonment of moral principles that fell into oblivion due to the pressure of the new "Hydras", as Hydro Power Stations are called in the novel "The Flood Zone".

\section{Statement of the Problem}

Despite the fact that by the end of the 1970s critics and literary scholars started talking about the decline of the classical "village prose" (V.G. Rasputin's story "Farewell to Matyora" published in 1976 was denoted as the final text of this literary style), already in the 1990s Russian and Western Slavists started speaking about the transformation of the "village prose" as a 
characteristic tendency of the literary process of the turn of the $20^{\text {th }}-21^{\text {st }}$ centuries.

Thus, S.Y. Korolev indicates this period not as the "end" of the direction, but as the next stage of its development, connected with the discovery of "dead ends" and, perhaps, the final one. The researcher says that many representatives of the "village prose" in their journalism referred to the global ideas of the world transformation (Korolev, 2006). K. Parthe (Parthe, 2004), N.V. Kovtun (Kovtun, 2013) and A.I. Razuvalova (Razuvalova, 2015) also mention this in their works.

In modern studies there is a conditional division of writers, whose works in different ways reflect the problems of village, into several groups.

Firstly, we are talking about the authors who formed a "younger generation" of the "village prose" (B.P. Ekimov and V.N. Krupin). The works of these writers are characterized by the realistic depiction of reality; images of the characters are developed in the manner of traditional psychologism. The story by V.N. Krupin "The $40^{\text {th }}$ Day" is represented as an act of commemoration and humility to the loss of native space and the person (Parthe, 2004: 151). It is not by chance that N.V. Kovtun calls B.P. Ekimov "the last villager", who finishes the strivings of traditionalism in contemporary literature (Kovtun, 2013). Traditional motifs and images of the fictional world of the writer summarize the problems and poetics of the classical "village prose", what is especially noticeable in the key texts of the author - "Holyushino Farmstead" and "The Shepherd's Star" (Kovtun, 2012: 255-264). The writer depicts a peasant, caught in the conditions of the turn of the epochs. Already in the story "Pinochet" (1999), the writer raises the question of not only survival of rural people, he states about the fundamental change in the ideology of life (Barakov, 2014). A new hero-savior is represented in the image of Korytin. His arrival is not associated with the prospect of the revival of patriarchal culture, rather with the chance for survival (Kovtun, 2013: 334).

Secondly, these are the writers who deliberately deviate from the ideological and aesthetic conception of traditionalist prose, largely trying to deconstruct the village myth ("The Country House" by A.N. Varlamov). The image of chronotop of the village goes to the field of conditional and ludic literary forms that travesty the classic examples ("Village Went Past the Peasant" O.I. Larin, "Far Sight of Forests" by B. Khazanov and "Village Stories" by L.A. Sycheva). The writers who are principally far from the village theme often turn to it ("The New Robinsons" and "The Country Diary" by L.S. Petrushevskaya, "Village Diaries" by V.A. P'etsukh). Folklore and mythological images and the plots get to the area of ironic interpretation ("The Night before Christmas" by V.A. Kirshin).

Thirdly, these are the local (regional) writers, who one way or another preserved the traditionalist range of problems in their works (O.G. Chetkarev, S.V. Matveev and G.A. Fedorov), where opposition of realistic and postmodernist tendencies is strong. Regional writers often refer to the image of a modern city, their characters experience a "crisis of ethnicity", but in the structure of the works the national image of the world presents as unalterably significant (Koroleva, 2006).

The American Slavic scholar K. Parthe notes that after the collapse of the "village prose" some traditionalist writers moved the settings to the urban environment. New settlements (Sosnovka in "The Fire" by V.G. Rasputin), provincial towns (Veisk in "The Sad Detective" by V.P. Astafiev), Moscow ("Everything is Ahead" by V.I. Belov, "The Last Sorcerer" by V.V. Lichutin) have become more important spaces for artistic analysis than village. However, despite this, it is important to note that these works were not only 
pro-village, they were anti-urban. The light tone of elegy disappears, only ruined past, gloomy present and the future, pictured in apocalyptic tones are left (Parthe, 2004).

The problematic issue is that first of all, late traditionalist prose is more descriptive and journalistic, there is a clear transition from the "village prose" (with its deep moral and ethical content) to the prose of the village, where the writers not so much resolve the issues of the moral existence as establish the fact of impoverishment and decline of the Russian village. Literary scholars refer Z. Prilepin, R.V. Senchin, A.N. Varlamov, S.M. Mishnev and A.Y. Kirov to the late traditionalists. Here the authors saw not only the costs of urbanization, but the continuation of the tragic process of "depeasantization", now at its new stage (Barakov, 2014).

I.N. Ivanova (Ivanova, 2013) notes that literary texts by T.Y. Kibirov ("Lada, or Joy”), T.V. Moskvina ("Shame and Purity"), A.V. Dmitriev ("The Peasant and the Teenager"), R.V. Senchin ("Eltyshevy”) and A.V. Ivanov ("Cynocephaly") should be referred to the new "village prose". It should be noted that the circle of these authors creates the range of problems and aesthetics of late traditionalist prose. Siberian prosaist M.A. Tarkovsky should be referred to the number of these representatives.

\section{M.A. Tarkovsky \\ as a Representative of Late Traditionalism}

Mikhail Aleksandrovich Tarkovsky is one of the representatives of modern Russian literature, whose literary texts should be referred to the late traditionalism. Within the frames of his own fictional world M.A. Tarkovsky implements plot constructs and motif complexes, sets the ideological and thematic direction and the range of problems, typical, in general, to the "village prose" poetics. The traditionalist worldview was already formed in the literary works of the early stage (Kovtun, 2013: 5-22). Fictional experience of the Siberian prosaist, according to A.I. Razuvalova, utterly demonstrates the ability (or opportunity) "to revive "a combination of ideologemes" characteristic of the "village prose" (Razuvalova, 2015: 552).

Nowadays, the idea of traditional values rethinking and an attempt to preserve national identity that deficiency under the conditions modern reality development is obvious, are mainly associated with the name M.A. Tarkovsky.

Flash prose of the writer should be conditionally divided into two creative stages that are connected logically and historically. From the description of the national identity crisis, marked by the early texts of the writer, the transition to the new traditionalist prose is made, the author considers the prospect of the cultural values preservation, an intellectual hero overcomes "civilizational exhaustion" by the intuitive advancement toward the natural foundations of existence. In the case of M.A. Tarkovsky, it is not a course "back" to primordial or hempen (and not even a course forward, if we understand it as a "progress"), but, rather, it is a special way, outlining the search of the internal sense, but not external - social and behavioral - stereotypes. The pathos of Tarkovsky's prose can be defined as a person's astonishment at the unknown and unexplored side of life revealed to him (Remizova, 2001). Critics state that in this respect the literary letter of M.A. Tarkovsky is ideologically close to the late prose by V.P. Astafiev.

In the conceptional texts of the early (and partly mature) period of work, the author focuses attention on the concepts of loss of the national culture, tradition, peasant's house and family that is typical of the late prose of the "villagers". Such stories as "Ice Drift", "Everlasting", "Petrovich", "Foundation" and such novels as "Construction of Banya", "Grandma's Alcohol" and "The Spoon of Soup" (Tarkovsky, 2014) should be referred to 
these works. The author's texts are full of nostalgic motifs, they preserve the idea of the patriarchal village, the writer outlines the traditional literary images (a peasant, a folk righteous, a patriarchal male type), which are gradually replaced by the image of the hero with crisis thinking. The ideas of self-sacrifice, individual estrangement and detachment from the world become the key ones in the text of the late traditionalist. The motif of departure/farewell/separation, ideologically inserted into the historical and literary situation of the turn of the $20^{\text {th }}-21^{\text {st }}$ centuries becomes the plot foundation of fictional narration.

Literary works of the mature period are characterizedbynatural-philosophicalorientation. Relationships of characters (fishermen, hunters and forwarders) with the world of nature are natural and inviolable. An intellectual hero (writer), who is not only an eyewitness of what is happening, but also a direct participant of the events of life in the forest, becomes the main literary character. Specific experience of the characters, their metaphysical perception of the live natural world, their own life, addressing to the issues of existence - this the way the traditionalist experience of the writer is formed and importance of the "simple life" is confirmed (Razuvalova, 2015: 553), at the same time idyllic chronotope, associated with the recreation his own sacred world space is constructed in the prose (Mitrofanova, 2014). Fictional space of the text is divided functionally: taiga is represented exclusively as the man's world and village as the woman's. M.A. Tarkovsky has ambiguous view on what is depicted: on the one hand, the surrounding is given in the perception of men-hunters, whom he reunites with, on the other, in the perception of a specific character - an intellectual, where it is possible to trace his metropolitan past: the images of Andrey in "The Forest" and Alexey in the story "Shashtyndyr". M.A. Tarkovsky, keeping the traits of civilized thinking in the image of the hero, solves the problem of rootedness in the world of idyll. As well as in the earlier texts of the writer, the conflict of urban and rural ("The Frozen Time", "Give Me Mine" and "Kondromo") is notable in his mature prose. A motif of spiritual purification and existential confession becomes a cross-cutting motif of fictional narration. Taiga becomes a sacred space; Siberia acquires the meaning of the blessed land, the topos of revival (Gabdullina, 2015). The writer refers to the problem of preserving the traditions, the revival of the peasant way of life, the restoration of inner harmony - this is the way the ethics prose by Tarkovsky is formed - upbringing of courageous character in the conditions of the wild taiga nature: the nature fosters those with the strong spirit and destroys the weak ones (Pavlov, 2005).

\section{The Crisis of Traditionalism}

\section{in the Flash Prose by M.A. Tarkovsky}

The image of the confessional character is represented in the early novel by M.A. Tarkovsky "Construction of Banya" (1998). The old man Ivanych is a God-given farmer, who devoted all his life to the service to earth and nature. The plot foundation of the work is construction of a new banya. It is significant that the process of construction of the building is accompanied by important events in the character's life that are embedded as memories in the course of narration. Constructing the building, the character as if is preparing to his own death - sums up his life, remembers the sins of the past, constructing a new dwelling.

Coming into another world happens through the banya where Ivanych is purified, as if reborn. The chronotope of the banya, represented as an infernal space in traditionalism, is sacralized within the boundaries of the text, acquires additional, confessional function that also refers to the plot by V.M. Shukshin ("Alyosha Without Escort"). The scene of entrance seems very 
symbolic: the character experiences children's excitement as before the "long-awaited event". Baring the body, Ivanych takes off his baptismal cross (leaves his earthly destiny on the banya's bench) - it is necessary to enter God renovated as a baby - the character as if returns to the First Principles. The final scene of death is interpreted as abandonment of sin, catharsis and finding peace and a new life, "all offences and annoyance went into the land and Ivanych's soul, that has never been so clean, flew to the sky" (Tarkovsky, 2014: 183).

Tarkovsky's character naturally overcomes the fear of death. It is indicative that this event takes place early in the morning when haymowing begins, a new life is born - the scene symbolizes the cyclical nature of existence. In general, the story of the writer is penetrated with nostalgic and utopian motifs. The author validates the image of the character that represents the old, patriarchal Russia. "The story of the prodigal son" is centrally inserted in the context of the works. Serega, the only son of Ivanych leaves his native place, violates his father's covenant and settles in the city residence hall (temporary and transitional space - the crossroads). The idea of leaving his father's house symbolizes the destruction of the patriarchal way of life - Sergei, leaving his native place, undermines life principles, thus, dooming themselves to voluntary homelessness and orphanhood. As well as V.M. Shukshin's characters, he is represented as a marginal character that can not self-identify, lives with the dreams of better life, without even trying to bring them to life.

The search for God, spiritual foundation and the motif of returning to the "blessed" land become an important ideological dominant of M.A. Tarkovsky's work. In the story "Grandma's Alcohol" (2004), the author reconstructs "the motif of the road of sorrows". The grandmother worries about her son, who fell into a "drunken stupor", she is sad for her scampish daughter Galka, "girl lost herself into drinking and sluttish" (Rusakov, 2004). But most of all her heart is bleeding for her grandson Kolka, who is "powerfully and permanently inculcated" from the ill-fated vodka from his childhood. We can see how the image of the martyr (passion-bearer), who humbly accepts all the hardships of earthly life, is revealed in the story.

The split of rural space into two camps the sober and the drunk (that conditionally resembles hell and heaven), where "on the one side they plow, but they don't care what happens on the other" (Tarkovsky, 2014: 252), where one side survives due to another, is explained by the destruction of tradition and former lifestyle. And Grandma, who is on the line of the split (right in the section) faces the sinful half of humanity; watching their sufferings, she suffers even more. And in this sense, the "the road of sorrows" is conceived as a service to sinful people. If in the Old Russian text the Holy Mother asks God for Christian sinners' forgiveness, Tarkovsky makes another, comparable to apocryphal, fictional decision - Granma atones for the sins of the people of the village with her death, as evidenced by the symbolic image of the bunting at the end of the story. The image of the wise old woman, the keeper and the patron, the key one for classical traditionalism, is revealed in the character by M.A. Tarkovsky.

The writer has the slightest hope for the preservation of the national identity in "Ice Drift" (2001), the author's idea is connected with the image of people's righteous aunt Nadia. The hospitable old woman, who experienced pain and loss in her life (the death of two husbands and her own daughter) remains faithful to the peasant's way of life. The destruction of rural space in the story is comparable to the aging home of the character, that reminds the sinking ship. Experiencing destruction and resettlement of the 
village, the character does not lose her former connection with it - left alone, she appears as the last keeper, the genius of the territory (Kovtun, 2013). In the new space, created by "outsiders", the character lives with the same traditions, being faithful to herself and preserving memory. Aunt Nadia is deprived of her old house - and even in the new house (as well as in the new village space) she arranges everything in the old way. In the image of aunt Nadia (the semantics of the name is associated with hope) the type of ascetic that comes down to the national image - the keeper of the ancient foundations, is outlined.

Internal breakdown of characters in the Siberian writer's work is associated with the crisis of national identity. Petrovich ("Petrovich", 2001) feels discord with life, spiritual orientation is lost. Initially, the motif of the character's wandering, who is disappointed in the realities of modern life, is given in the plot of narration (Rybal'chenko, 2013) - the image of the fringe, whose wandering is caused by the external (primarily, social) circumstances is formed. The collapse of the rural space (in the narrator and the protagonist' minds) signifies the search of a new identical world. The character's journey to the foreign lands (Petrovich goes to the west, which is equivalent to death/destruction) does not help to establish himself, that logically precedes the character's return home. On the other hand, this journey helps Petrovich to gain new knowledge. Meeting with Pavlik and his wife is a kind of experience of the worldly wisdom comprehension, which helps the character to rethink his past life. The situation of the character's returning home is ambiguous: on the one hand, the author confirms the idea of the "big center" sacredness (return to Bakhta), on the other hand - the return is revealed as collapse of the "small center" values (the topos of home). At the end of the story the character establishes his own "intermediate" position, "I will not come back to the woman, I will stay at Pavlik's, and then I will build a log house" (Tarkovsky, 2014: 10).

The crisis of traditionalism, traced in the iconic texts by Tarkovsky, indicates a boundary character, who starts seeking for justification to his/her own actions, to save him/herself under conditions of spiritual decline, selflessly helping a neighbor. The author shows foolishness as a sign of the time, and fool-for-Christ Van'ka ("Foundation") becomes a symbol of the epoch: "He looked like a blind lyre or psaltery player, who came from a depthless antiquity to sing for and to mourn our foolish time" (Tarkovsky, 2014: 116). "The cry" of the fool-for-Christ (in the course of the heart to heart talk of the characters, and Van'ka refuses the money for his work on the house construction) becomes an atonement. "Foundation" will become an iconic work for the writer, in the image of an intellectual Fedor (who "hosted" a wanderer, and in fact, prepared Van'ka to a new life) the author sees the chance to save the present. In this type of character the key features of the national village character fairness, conscientiousness, selflessness and human relation to his neighbor are outlined, but the image is devoid of illusions about the revival of the old style of life, retaining the position of personal self-identity in the world-chaos.

\section{Resume}

Thus, finalizing the poetics of traditionalism at the turn of the $20^{\text {th }}-21^{\text {st }}$ centuries, M.A. Tarkovsky is simultaneously rethinking the fate of the Russian people. From the description of the rural way of life the writer comes to recreating the harsh life of a taiga settlement, cut off from the world, a hunter and a fisherman replace a real peasant. From the ethic prose author goes to natural philosophy, introducing the character of intellectual consciousness, who is reconnected with the world of nature. An intellectual is given an important role - he has to investigate the 
possibility of return from the space of civilization to the traditional sources of life (to the village). M.A. Tarkovsky's characters are quite varied: while some of them "overcome life", have tough luck, acknowledge and leave the sinful world, others simply resist the evil spirit of the time, trying to purify and heal their soul in the space of the Siberian taiga. Narrative prose of the writer in its own way renews classical literary tradition - a character from the world of civilization joins the character from the world of rural idyll, a reunion of the two Russian national types - peoples and intellectual takes place, reviving the national cultural model (Mitrofanova, 2009).

Reasoning about the future of realism in contemporary Russian literature critic V. Bondarenko mentioned its three main directions: traditional, ludic and, figuratively speaking, naturalistic. He unites M. Tarkovsky with the representatives of the first direction - Varlamov, Pavlov and Basinsky, calling these authors "traditionalists of a new generation" (Bondarenko, 2004). The critic reflects that they have become new realists not in the form, but by the challenge that they have thrown to the dominant postmodernism within the frames of a single liberal direction. Their realism was surprising against the background of the destroyers of the forms and traditions of Russian literature who, according to the researcher, occupied the dominant positions in the modern literary process (Bondarenko, 2004).

Thus, studying the narrative works of the writer, it should be noted that in the context of traditionalism M.A. Tarkovsky's prose is ambivalent: the author defines the boundary of the transition from the late traditionalist prose literature to a new village literature, which is aimed to rethink the problem of defarming, not from the moral, but from the ontological and metaphysical positions (Barakov, 2014). It is symptomatic that understanding of tradition in fictional ideology of the writer is transformed it is "materialized and aestheticized", and is composed of the skills of adaptation to nature and applied labor (Razuvalova, 2015: 553). The writer steps into a new stage of work, associated if not with restoration, then with preserving rural traditions and formation of new ideological and aesthetic principles in the contemporary literature. In this respect, modern scholars are inclined to speak of the "new village prose" (Yakushev, 2013), "traditionalism of a new generation", patriotic literature (Bondarenko, 2004), the "new prose about village" (Barakov, 2014), modern "traditional" literature (Kotlov, 2011), traditionalist prose (Kovtun, 2013b), etc. The representatives of this direction do not try to oppose the city and the village; their searches are directed not to the past or the future, but to the present and eternity, because it is spiritual principles that determine historical fate of the nation. The new prose about the village (or neo-traditionalist prose - auth.) evidences of a dramatic return to the classical tradition and of the search for a spiritual foundation (Barak, 2014). M.A. Tarkovsky repeatedly mentions this in his key works.

\section{References}

Abramov, F.A. (1993). Ia pishu o Severe [I Write About the North]. SPb, 5, 10-11.

Barakov, V. (2014). Ot derevenskoi prozy k proze o derevne [From Village Prose to Prose About Village], In Parus. Available at: http://parus.ruspole.info/node/5901 (Accessed: 15 December 2015).

Belov, V.I. (1993). Vnemli sebe. Zapiski smutnogo vremeni [Listen to Yourself. Notes of the Time of Troubles]. Moscow, Skify, 141 p. 
Belyaeva, N.V. (2014). Nekotorye aspekty izucheniia sovremennoi prozy [Some Aspects of Studying Modern Prose], In Uchitel'skoe soobshchestvo [Teachers Community]. Available at: http:// uchitel.uss.dvfu.ru/wp-content/uploads/2014/07/Беляева-Н.В.-Некоторые-аспекты-изуч.-совр.прозы.pdf (Accessed: 19 December 2015).

Bondarenko, V. (2004). Novyi realism [New Realism], In Den' Leteratury [The Day of Literature]. Available at: http://fanread.ru/book/4306364/?page=1 (Accessed: 19 November 2015).

Gabdullina, V.I. (2015). Motif “vozrozhdeniia Sibir'iu” v epistoliarnom, khudozhestvennom i publitsisticheskom diskurse Dostoevskogo [The Motif of "Revival by Siberia" in Epistolary, Narrative and Journalistic Discourse of Dostoevsky], In Altaiskii tekst v russkoi kul'ture [Altai Text in Russian Culture], (6), 86-98.

Ivanova, I.N. (2013). Derevenskaia proza v sovremennoi otechestvennoi literature: konets mifa ili perezagruzka [Village Prose in the Modern Russian Culture: the End of Myth or Reloading], In Fililogicheskie nauki. Voprosy teorii i praktiki [Philological Sciences. Issues of Theory and Practice], (6), 88-94.

Kovtun, N.V. (2013). Patriarchal'nyi mif v traditsionalistskoi prose rubezha 20-21 vv. [Patriarchal Myth in the Traditionalist Prose of the Turn of the $20^{\text {th }}-21^{\text {st }}$ Centuries], In Sibirskii philologicheskii zhurnal [Siberian Philological Journal], (1), 77-87.

Kovtun, N.V., Stepanova V.A. (2014). Problema gendernoi identifikatsii muzhskikh obrazov v tvorchestve V. Rasputina [The Problem of Gender Identification of Men's Images in V. Rasputin's Creative Work], In Philologicheskii klass [Philological Class], 2 (36), 7-14.

Kovtun, N.V. (2013). Sovremennaia traditsionalistskaia proza: ideologiia i miphopoetika [Modern Traditionalist Prose: Ideology and Mythopoetics]. Krasnoyarsk, SibFU, 352 p.

Kovtun, N.V. (2010). Iurodskoe stranstvie v poetike F. Abramova [Fool-for-Christ's Wandering in F. Abramov's Poetics], In Sibirskii philologicheskii zhurnal [Siberian Philological Journal], (3), 93-102.

Kovtun, N.V. (2012). House-spirit, Master, Pinochet: a Patriarchal Myth in the Late Traditional Prose, In Journal of Siberian Federal University. Humanities and Social Sciences, 2 (5), 255264.

Koroleva, S.Y. (2006). Khudozhestnvenny miphologism v proze o derevne 1970-90-kh godov [Fictional Mythologism in the Prose about Village of the 1970s - 90s], Perm, $191 \mathrm{p}$.

Kotlov, A.K. (2011). Sovremennaia russkaia "traditsionalistskaia proza": nekotorye aspekty evoliutsii [Modern Russian "Traditionalist Prose": Some Aspects of Evolution], In Vestnik KGY im. N.A. Nekrasova [Bulletin of KSU named after N.A. Nekrasov], (2), 141-145.

Leiderman, N.L., Lipovetsky, M.N. (2003). Sovremennaia russkaia literatura: 1950-1990-e [Modern Russian Literature: the 1950s - 1990s]. Moscow, Publishing House "Akademia", 688 p.

Mitrofanova, A.A. (2009). Idilliia Mikhaila Tarkovskogo [Idyll of Mikhail Tarkovsky], In Sovremennost'v zerkale refleksii: yazyk-kul'tura-obrazovanie: materialy mezhdunarodnoi nauchnoi konferentsii [Modernity in the Mirror of reflection: Language - Culture - Education: Proceedings of International Scientific Conference]. Irkutsk, ISU, 432-438.

Pavlov, O. (2005). Puti i propy [Roads and Paths], In Topos: literaturno-philosophskii zhurnal [Topos: Literary and Philosophic Journal]. Available at: http://www.topos.ru/article/3196?page=1 (Accessed: 12 November 2015). 
Parthe, K. (2004). Russkaia derevenskaia proza: svetloe proshloe [Russian Village Prose: The Radiant Past]. Tomsk, Tomsk University Publishing House, 204 p.

Razuvalova, A.I. (2015). Pisateli-“derevenshchiki”: literatura i konservativnaia ideokogiia 1970-kh godov [Writers-"Villagers": Literature and Conservative Ideology of the 1970s]. Moscow, Novoe literaturnoe obozrenie, $616 \mathrm{p}$.

Rasputin, V.G. (1991). Vozvrashchenie Rossii [Return of Russia], In Siberia, (1), 3-4.

Remizova, M. (2001). Proryv iz kruga [Breakthrough from the Circle], In Russkii Zhurnal [Russian Journal]. Available at: http://old.russ.ru/krug/kniga/20011224-pr.html (Accessed: 27 December 2015).

Rusakov, E. (2004). Dobraia babushka i zlaia zhizn' (o povesti Mikhaila Tarkovskogo “Babushkin spirt") [Kind Grandma and Evil Life (on the Story of Mikhail Tarkovsky "Grandma's Alcohol")]. Krasnoyarsky rabochii, 115, 3 .

Rybal'chenko, T.L. (2013). Siuzhet brodiazhnichestva i novaia kartina mira v sovremennoi russkoi literature [The Plot of Wandering and a New Worldview in the Modern Russian Literature], In Bulletin of Tomsk State University. Philology, 6 (26), 87-100.

Tarkovsky M.A. (2014). Izbrannoe [Selected Works]. Novosibirsk, Istoricheskoe nasledie Sibiri [Historical Heritage of Siberia], $496 \mathrm{p}$.

Yakusheva, O.A. (2012). Tema pravednichestva $\mathrm{v}$ novoi derevenskoi proze [The Topic of Righteousness in the New Village Prose], In Vestnik Brianskogo gosuniversiteta [Bulletin of Bryansk State University], 2 (2), 178-180. 


\title{
Малая проза М.А. Тарковского
}

в контексте традиционализма:

завершение направления vs. иная перспектива

Н.А. Вальянов

Сибирский федеральный университет Россия, 660041, Красноярск, пр. Свободный, 79

\begin{abstract}
Малая проза современного сибирского писателя М.А. Тарковского рассматривается критиками и литературоведами в контексте позднего традиционализма. Мотив хаоса и утраты национального/традиционного, актуальный для постдеревенской литературы, становится ведущим в прозе намеченного писателя, идеально прослеживается в художественных текстах Р.В. Сенчина, А.Н. Варламова, О.О. Павлова и др. Собственно сам художник обозначает границу перехода от кризиса национального самосознания к проблеме переосмысления и сохранения исконных иенностей. Герою-интеллигенту суждено вернуться $\kappa$ народным истокам, воссоединиться с природным миром, почувствовать подлинную экзистенцию. В художественном мире М.А. Тарковского конструируется иной способ выживания: писатель формирует идеологию отшельничества, утверждает собственную культурно-географическую маргинальность (А.И. Разувалова). В малой прозе автора трансформируется понимание традиии как важнейшей категории человеческого бытия.

Ключевые слова: современная традиционалистская проза, деревенская проза, Михаил Тарковский, неореализм, интеллигент, крестьянин, охотник, промысловик, маргинал, праведник.
\end{abstract}

Научная специальность: 10.00.00 - филологические науки. 